\title{
Water Needs of the Ash-Leaved Maple (Acer negundo L.) at the Period over Three Years after Reclamation in Different Regions of Poland
}

\author{
Stanisław Rolbiecki ${ }^{*}$, Roman Rolbiecki ${ }^{1 *}$, Barbara Jagosz ${ }^{2}$, Wiesława \\ Kasperska-Wołowicz ${ }^{3}$, Wiesław Ptach ${ }^{4}$, Piotr Stachowski ${ }^{5}$, Anna Figas ${ }^{6}$, \\ Vilda Grybauskiene ${ }^{7}$, Andrzej Klimek ${ }^{8}$, Cezary Podsiadło ${ }^{9}$
}

1 Department of Agrometeorology, Plant Irrigation and Horticulture, University of Science and Technology in Bydgoszcz, Bernardyńska 6, 85-029 Bydgoszcz, Poland

2 Institute of Plant Biology and Biotechnology, University of Agriculture in Krakow, 29 Listopada 54, 31-425 Krakow, Poland

3 Institute of Technology and Life Sciences in Falenty, Kuyavian-Pomeranian Research Centre, Glinki 60, 85-174 Bydgoszcz, Poland

4 Department of Engineering and Geodesy, Warsaw University of Life Sciences, Nowoursynowska 159, 02-776 Warszawa, Poland

5 Poznań University of Life Sciences, Faculty of Environmental Engineering and Spatial Management, Institute of Land Improvement, Environmental Development and Geodesy, Piątkowska 94, 60-649 Poznań, Poland

6 Department of Plant Genetics, Physiology and Biotechnology, University of Science and Technology in Bydgoszcz, Bernardyńska 6, 85-029 Bydgoszcz, Poland

7 Institute of Water Resources Management, Aleksandras Stulginskis University in Kaunas, Studentu g. 10, Lithuania

8 Department of Zoology and Landscaping, University of Science and Technology, Kordeckiego 20, 85-225 Bydgoszcz, Poland

9 Department of Plant Production and Irrigation, West Pomeranian University of Technology in Szczecin, Słowackiego 17, 71-430 Szczecin, Poland

* Corresponding author's e-mail: rolbr@utp.edu.pl, rolbs@utp.edu.pl

\begin{abstract}
The ash-leaved maple (Acer negundo L.) has low habitat requirements, which is why this species is often used in the reclamation of industrial areas. The development of the reclamation plantings depends on the optimal water soil conditions that can be controlled by watering treatments. However, the use of irrigation requires determining the water needs of the cultivated species. The objective of the study was to evaluate the water needs of the ashleaved maple in the reclamation plantings, in the period of over three years after planting. The water needs of the ash-leaved maple were determined using the crop coefficients method. Potential evapotranspiration was calculated using the Blaney-Criddle's formula that was modified for the Polish conditions by Żakowicz. The water needs of the ash-leaved maple were assessed for five agro-climatic regions of Poland, in the years 1981-2010. The water needs of the ash-leaved maple in the growing period (April-October) were the highest in the C-E (638 $\mathrm{mm})$ and $\mathrm{C}-\mathrm{N}-\mathrm{W}(637 \mathrm{~mm})$ regions, and the lowest in the N-E $(598 \mathrm{~mm})$ and S-E $(601 \mathrm{~mm})$ regions. In July, the highest water needs were noted in the C-N-W region $(149 \mathrm{~mm})$ and the lowest in the S-W region $(129 \mathrm{~mm})$. In the studied thirty-years period, there was a significant upward trend in the water needs of the ash-leaved maple both during the growing season (except for the C-N-W region) and in July, in all the considered regions.
\end{abstract}

Keywords: irrigation, potential evapotranspiration, rainfall deficiencies, water requirements

\section{INTRODUCTION}

One of the basic reclamation treatments is the introduction of many different plant species, including trees and shrubs, which create a suitable landscape and microclimate on the reclaimed areas. The ash-leaved maple (Acer negundo L.) is the most popular alien species of maple in Poland 
[Danielewicz and Wiatrowska 2014]. Easy reproduction and cultivation of the ash-leaved maple make it is common for use in the tree plantings, especially along the roads, in the neighborhood of water, in villages, cities and parks as well in the reclamation of industrial areas as the screen plants. The plant development on the reclaimed areas depends on the optimal water soil conditions, which in turn can be controlled by properly operated watering treatments [Żakowicz 2010]. However, the designing of irrigation system requires firstly the determination of the water needs of the cultivated species.

The aim of the presented research was to calculate the water needs of the ash-leaved maple in the reclamation plantings, over the period of three years after planting.

\section{MATERIAL AND METHODS}

The water needs of the ash-leaved maple (Acer negundo L.) in the period of over three years after reclamation were determined using the crop coefficients method. Potential evapotranspiration was calculated using the Blaney-Criddle's formula that was modified for the Polish conditions by Żakowicz [2010]. The water needs of the ash-leaved maple in the years 1981-2010 were assessed for five agro-climatic regions of Poland [Łabędzki et al. 2013] with the representative meteorological stations located in Olsztyn, Bydgoszcz, Warszawa, Wrocław and Kraków (Fig. 1). The rainfall deficiencies with the probability of occurrence $\left(\mathrm{N}_{50 \%}, \mathrm{~N}_{25 \%}\right.$ and $\left.\mathrm{N}_{10 \%}\right)$ were determined by the Ostromęcki's method [Żakowicz et al. 2009].

\section{RESULTS}

The variability related to the water needs of the ash-leaved maple in the period of AprilOctober, expressed by the variability coefficient, ranged from $2.7 \%(\mathrm{C}-\mathrm{N}-\mathrm{W}$ region) to $2.9 \%(\mathrm{~S}-\mathrm{W}$ and $\mathrm{S}-\mathrm{E}$ regions) (Tab. 1). In the month with the greatest water needs - July - the variability coefficient value ranged from $5.5 \%$ (S-E region) to $6.4 \%$ (C-N-W region).

In all the studied regions, a tendency to increase the water needs of the ash-leaved maple during the growing season (IV-X) in the

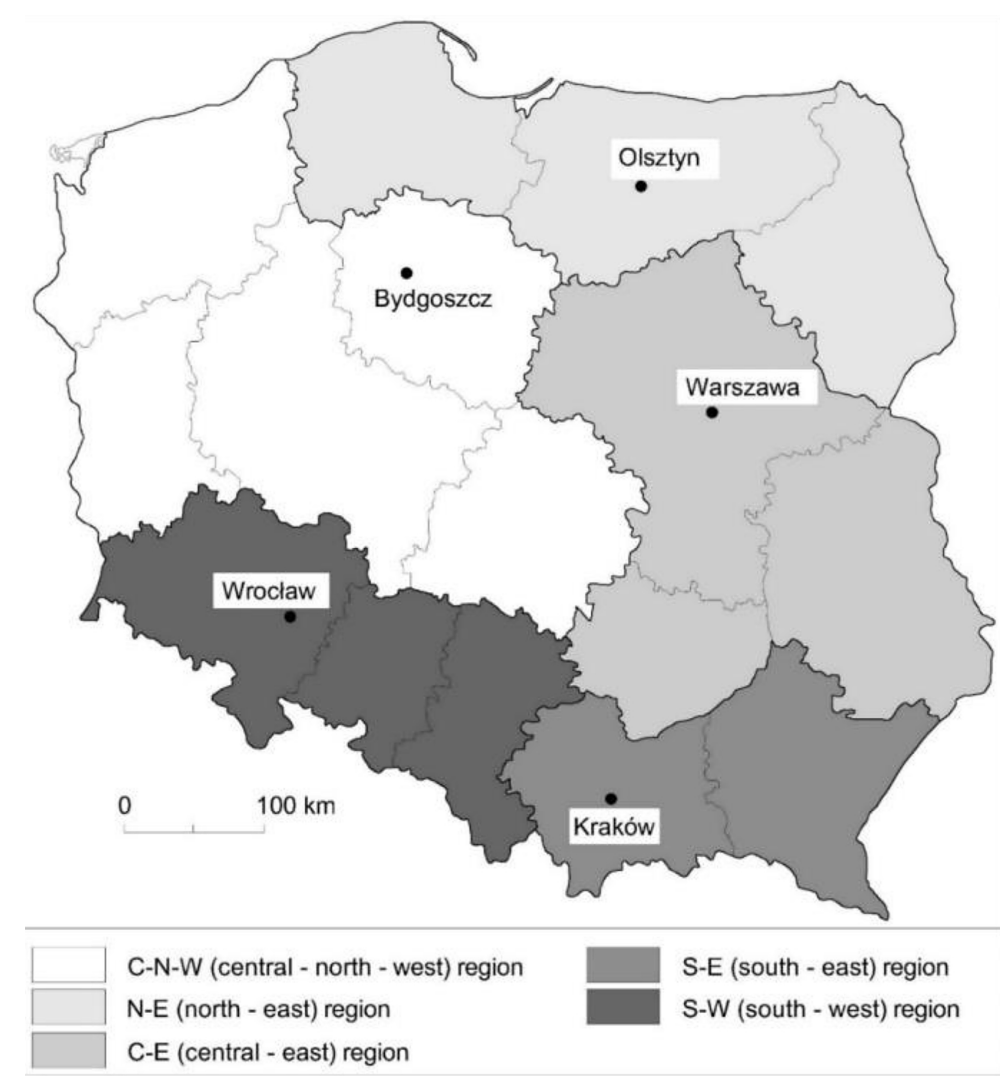

Figure 1. Agro-climatic regions of Poland with the representative meteorological stations [according to Labędzki et al. 2013] 
considered thirty-years period (1981-2010) was observed (Fig. 2). It should be noted that the trend of temporal variability of the ash-leaved maple water needs was significant for each studied region. The weakest relation (for $\alpha=0.1$ or $p$ $=90 \%)$ occurred in the $\mathrm{C}-\mathrm{N}-\mathrm{W}$ region. In other considered regions, the significance was much stronger (for $\alpha=0.01$ or $p=99 \%$ ).

In each ten-year period of the studied thirtyyears, the water needs of the ash-leaved maple increased in the time from April 1 to October 31 , in the range from $6.7 \mathrm{~mm}$ (C-N-W region) to $11.4 \mathrm{~mm}$ (S-E region). On average, in the years 1981-2010, considered for the five studied regions, covering all of Poland, the water needs of the ash-leaved maple during the growing season (April-October) increased by $10 \mathrm{~mm}$ in each ten-years period.

The highest water needs of the ash-leaved maple in the growing season, on average in the years 1981-2010, occurred in the C-E $(638 \mathrm{~mm})$ and $\mathrm{C}-\mathrm{N}-\mathrm{W}(637 \mathrm{~mm})$ regions, and the smallest in the N-E $(598 \mathrm{~mm})$ and S-E $(601 \mathrm{~mm})$ regions. (Fig. 3). A similar relationship was noted in July
- the month with the largest water needs during the growing season - then the highest monthly water needs of the ash-leaved maple were observed in the C-N-W region (149 mm), and the lowest in the S-W region $(129 \mathrm{~mm})$.

In all studied regions of Poland, a tendency to increase the water needs of the ash-leaved maple in July was observed (Fig. 4). In all considered regions, with the exception of the $\mathrm{C}-\mathrm{N}-\mathrm{W}$ region, a significant the trend of temporal variability of ash-leaved maple water needs was noted.

In each ten-year period of the considered thirty-years, in July, the water needs of the ashleaved maple significantly increased, in the range from $3.4 \mathrm{~mm}$ (S-W region) to $4.4 \mathrm{~mm}$ (C-E region). A non-significant trend of temporal variability of the ash-leaved maple water needs in the $\mathrm{C}-\mathrm{N}-\mathrm{W}$ region was $2.6 \mathrm{~mm}$. On average, in the years 1981-2010 considered for the five studied regions, covering all of Poland, in July, the water needs of the ash-leaved maple increased by 3.8 $\mathrm{mm}$ in each ten-year period.

Rainfall deficiencies in the summer half-year (from April 1 to September 30) as well in July,

Table 1. Water needs of the ash-leaved maple during the vegetation period

\begin{tabular}{|c|c|c|c|}
\hline Specification & Region of Poland & April-October & July \\
\hline \multirow{5}{*}{ Minimum (mm) } & north-east (N-E) & 557.2 & 127.6 \\
\hline & central-north-west (C-N-W) & 597.5 & 132.8 \\
\hline & central-east (C-E) & 596.8 & 130.1 \\
\hline & south-west (S-W) & 595.6 & 113.5 \\
\hline & south-east (S-E) & 571.1 & 120.9 \\
\hline \multirow{5}{*}{ Maximum (mm) } & north-east (N-E) & 636.9 & 160.1 \\
\hline & central-north-west (C-N-W) & 673.3 & 171.6 \\
\hline & central-east (C-E) & 679.0 & 170.3 \\
\hline & south-west (S-W) & 667.1 & 148.7 \\
\hline & south-east (S-E) & 631.2 & 152.2 \\
\hline \multirow{5}{*}{ Median (mm) } & north-east (N-E) & 602.0 & 143.3 \\
\hline & central-north-west (C-N-W) & 636.9 & 150.1 \\
\hline & central-east (C-E) & 636.4 & 148.0 \\
\hline & south-west (S-W) & 631.0 & 129.4 \\
\hline & south-east (S-E) & 603.1 & 138.7 \\
\hline \multirow{5}{*}{$\mathrm{SD}(\mathrm{mm})$} & north-east (N-E) & 17.0 & 8.7 \\
\hline & central-north-west (C-N-W) & 17.5 & 9.6 \\
\hline & central-east (C-E) & 17.9 & 9.0 \\
\hline & south-west (S-W) & 18.2 & 7.8 \\
\hline & south-east (S-E) & 17.6 & 7.6 \\
\hline \multirow{5}{*}{ VC (\%) } & north-east (N-E) & 2.8 & 6.1 \\
\hline & central-north-west (C-N-W) & 2.7 & 6.4 \\
\hline & central-east (C-E) & 2.8 & 6.1 \\
\hline & south-west (S-W) & 2.9 & 6.1 \\
\hline & south-east (S-E) & 2.9 & 5.5 \\
\hline
\end{tabular}

Explanations: SD - standard deviation, $\mathrm{VC}$ - variability coefficient 

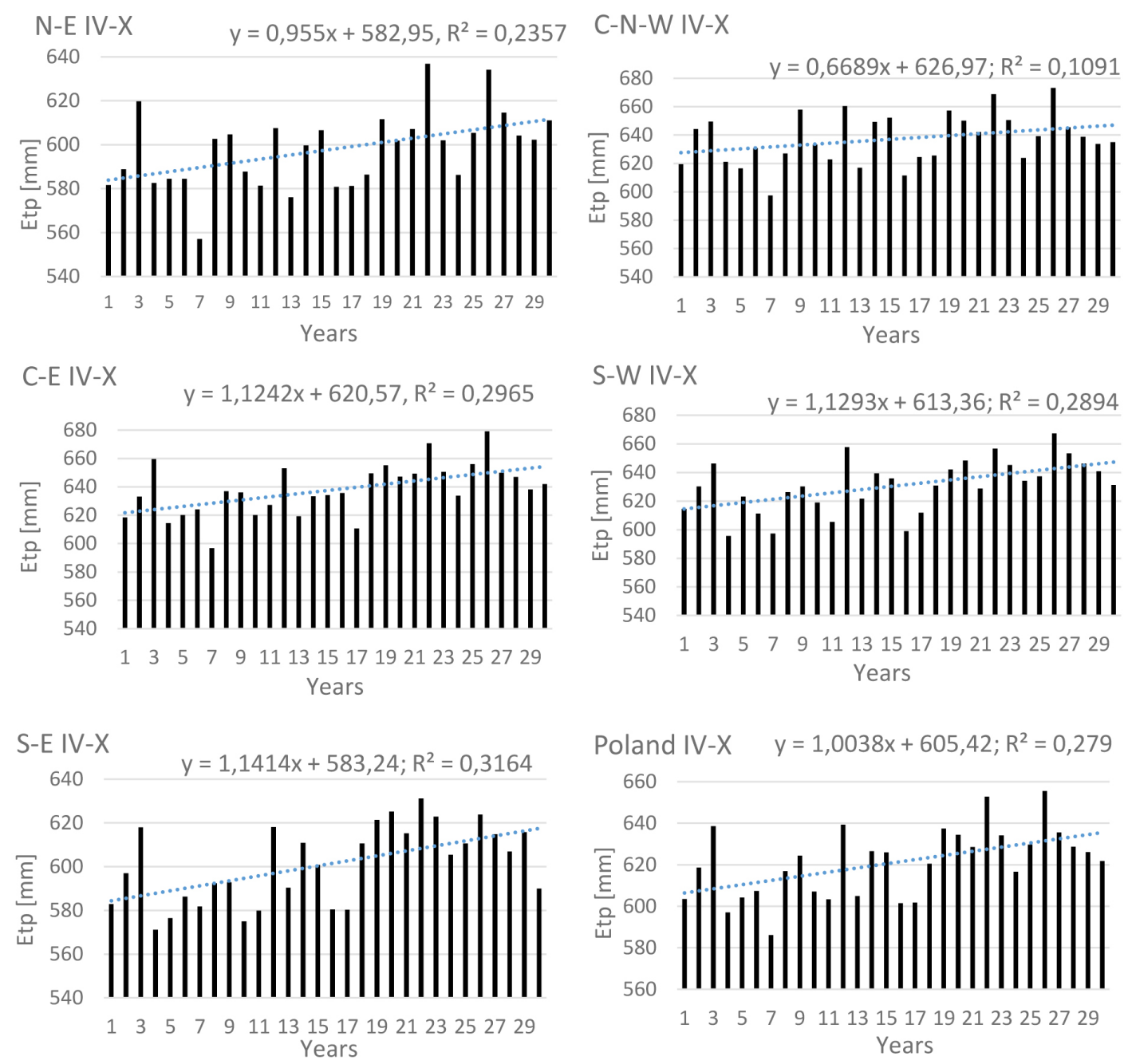

Figure 2. Temporal variability of the ash-leaved maple water needs in the period of April-October at the stage over three years after reclamation in the different regions of Poland
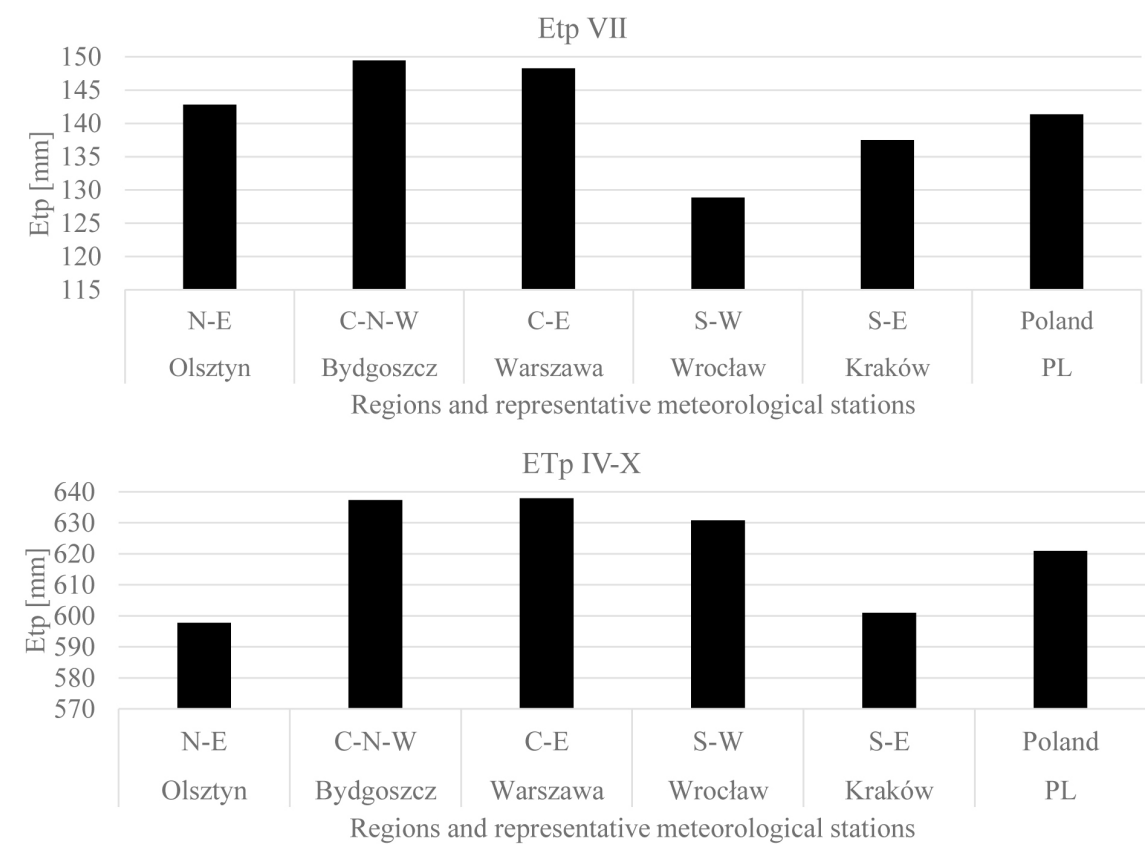

Figure 3. Water needs (ETp) of the ash-leaved maple in the growing period (April-October) and in July observed in the different regions of Poland 

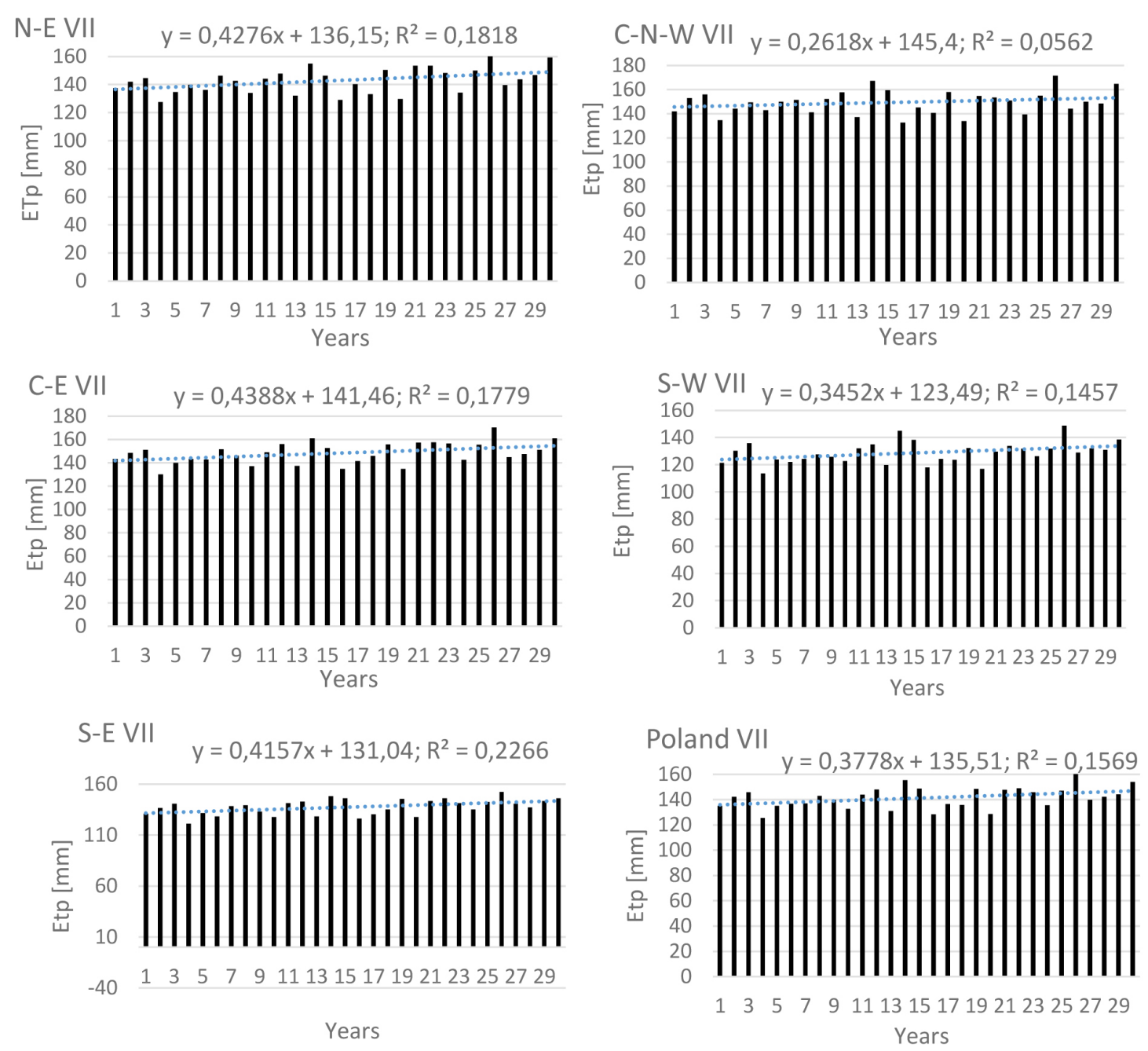

Figure 4. Temporal variability of ash-leaved maple water needs in July at the period over three years after reclamation observed in the different regions of Poland

are presented (Table 2). October was omitted, because of excess rainfall (from 5 to $16 \mathrm{~mm}$ ) noted in this month in the N-E and S-E regions. In the other studied regions, rainfall deficiencies were observed ( $\mathrm{N}_{50 \%}$ in the 5-8 mm range).

In the period of April-September, the highest precipitation deficiencies $\left(\mathrm{N}_{50 \%}\right.$ and $\left.\mathrm{N}_{25 \%}\right)$ were detected in the $\mathrm{C}-\mathrm{N}-\mathrm{W}$ region, where they amounted to $289 \mathrm{~mm}$ and $439 \mathrm{~mm}$, respectively. The highest precipitation deficiencies $\left(\mathrm{N}_{10 \%}\right)$, in the period of April-September, were noted in the C-E region $(576 \mathrm{~mm})$ that according to Żakowicz et al. [2009] covers $90 \%$ of the ash-leaved maple water needs. The smallest precipitation deficiencies in the period of April-September occurred in the S-E region, where they amounted to $121 \mathrm{~mm}, 284 \mathrm{~mm}$ and $360 \mathrm{~mm}$ for $\mathrm{N}_{50 \%}, \mathrm{~N}_{25 \%}$ and $\mathrm{N}_{10 \%}$, respectively.

In July, the highest rainfall deficiencies, ranged from $71 \mathrm{~mm}\left(\mathrm{~N}_{50 \%}\right)$ to 168 and $175 \mathrm{~mm}\left(\mathrm{~N}_{10 \%}\right)$, in the C-E and C-N-W regions, respectively, were observed, whereas the lowest - in the range from
$49 \mathrm{~mm}\left(\mathrm{~N}_{50 \%}\right)$ to 130 and $136 \mathrm{~mm}\left(\mathrm{~N}_{10 \%}\right)$ were noted in the S-E and S-W regions, respectively,.

\section{DISCUSSION}

In all regions of Poland considered in the presented study, during the thirty-year period of 1981-2010, a tendency to increase the water needs of the ash-leaved maple during the growing season was observed. This trend was previously reported by Labędzki [2009]. It is anticipated that in the near future the observed climate changes will cause an increase in the water needs of plants, including also the reclamation plantings. Therefore, it is necessary to undertake adaptation activities, among which the most effective are irrigation treatments, the importance of which will increase with the forthcoming climate changes [Rolbiecki et al. 2000, Łabędzki 2009, Stachowski 2009, Stachowski and Markiewicz 2011, 
Table 2. Rainfall deficiency $(\mathrm{N})$ of the ash-leaved maple in the period over three years after reclamation in the different regions of Poland

\begin{tabular}{|c|c|c|c|c|c|}
\hline \multirow{2}{*}{ Rainfall deficiency $(\mathrm{mm})$} & \multicolumn{5}{|c|}{ Region of Poland } \\
\cline { 2 - 6 } & $\mathrm{N}-\mathrm{E}$ & C-N-W & C-E & S-W & S-E \\
\hline \multicolumn{7}{|c|}{ April-September } \\
\hline $\mathrm{N}_{50 \%}$ & 200 & 289 & 244 & 238 & 121 \\
\hline $\mathrm{N}_{25 \%}$ & 402 & 439 & 426 & 371 & 284 \\
\hline $\mathrm{N}_{10 \%}$ & 531 & 534 & 576 & 495 & 360 \\
\hline $\mathrm{N}_{5 \%}$ & 69 & 71 & 71 & 49 & 49 \\
\hline $\mathrm{N}_{25 \%}$ & 124 & 134 & 127 & 87 & 103 \\
\hline $\mathrm{N}_{10 \%}$ & 148 & 175 & 168 & 136 & 130 \\
\hline
\end{tabular}

Żarski et al. 2013, Kuchar et al. 2015, Kuchar et al. 2017, Rolbiecki et al. 2017].

Irrigation is one of the most important melioration techniques that ensure the proper development of the tree and shrub seedlings in plantings and cultivations, among others in forest nurseries and other plantings [Rzekanowski and Pierzgalski 2006, Ptach et al. 2017]. The results obtained in the presented research may be helpful in planning and programming the irrigation treatments of the ashleaved maple. The results of many experiments carried out in the region of Bydgoszcz indicate a positive effect of irrigation - often observed in the interaction with other melioration (revitalization) methods - on the growth of seedlings of many species of trees, including: the European larch [Klimek et al. 2011], littleleaf linden [Klimek et al. 2013] and paulownia [Ptach et al. 2017].

The usefulness of a micro-irrigation system applied for watering of the ash-leaved maple grown in reclamation plantings was confirmed in field studies reported by Żakowicz [2010] as well Żakowicz and Hewelke [2012]. A positive response of the ash-leaved maple to the irrigation techniques was also presented in the experiments published by Roberts and Schnipke [1987], and Ranney et al. [1990]. High survival rate of the plants introduced into the reclaimed area depends on both the proper selection of the tree or shrub species and the provision of appropriate amounts of water, for example using the irrigation system [Żakowicz 2010, Biniak-Pieróg et al. 2016]. The ash-leaved maple has low habitat requirements, among others; it is resistant to drought [Cerny et al. 2002, Pacewicz et al. 2006, Frączek et al. 2009, Sjöman et al. 2015]. A positive reaction to irrigation may be related to the fact that Acer negundo uses shallow soil water (fed by rainfall) throughout the year in differing amounts [White and Smith 2015]. One of water source utilization studies suggested that Acer negundo and
Betula nigra rely significantly on deep ground water sources, supplemented with shallower soil water uptake during the period of June-September [White and Smith 2013].

\section{CONCLUSIONS}

1. In the years 1981-2010, during the growing period (April-October), the water needs of the ash-leaved maple in the second stage of reclamation (i.e. in the period of over three years after reclamation) were the highest in the C-E $(638 \mathrm{~mm})$ and $\mathrm{C}-\mathrm{N}-\mathrm{W}(637 \mathrm{~mm})$ regions, and the lowest in the N-E $(598 \mathrm{~mm})$ and S-E (601 $\mathrm{mm}$ ) regions.

2. In July, the month with the largest water needs during the growing season, the highest monthly water needs of the ash-leaved maple were noted in the C-N-W region $(149 \mathrm{~mm})$ and the lowest in the $\mathrm{S}-\mathrm{W}$ region $(129 \mathrm{~mm})$.

3. In the studied thirty-year period, there was observed a significant upward trend in the water needs of the ash-leaved maple both during the growing season (except for the $\mathrm{C}-\mathrm{N}-\mathrm{W}$ region) and in July, in all the considered regions.

4. The highest rainfall deficiencies $\left(\mathrm{N}_{50 \%}\right.$ and $\left.\mathrm{N}_{25 \%}\right)$ during the period of April-September were noted in the $\mathrm{C}-\mathrm{N}-\mathrm{W}$ region, where amounted to 289 and $439 \mathrm{~mm}$, respectively. In the period of April-September, the highest precipitation deficit $\left(\mathrm{N}_{10 \%}\right)(576 \mathrm{~mm})$ was observed in the C-E region.

5. In July, the rainfall deficiencies were the highest and ranged from $71 \mathrm{~mm}\left(\mathrm{~N}_{50 \%}\right)$ to 168 and $175 \mathrm{~mm}\left(\mathrm{~N}_{10 \%}\right)$ in the C-E and C-N-W regions, respectively, and the lowest in S-E and S-W regions, where they ranged from $49 \mathrm{~mm}\left(\mathrm{~N}_{50 \%}\right)$ to 130 and $136 \mathrm{~mm}\left(\mathrm{~N}_{10 \%}\right)$, respectively. 


\section{REFERENCES}

1. Biniak-Pieróg M., Żyromski A., Rolbiecki R., Rolbiecki S., Żyromski M. and Żmuda R. 2016. Effect of thermal conditions and precipitation on growth rate of Scots pine. Journal of Ecological Engineering, 17(5), 1-8.

2. Cerny T.A., Kuhns M., Kopp K.L. and Johnson M. 2002. Efficient irrigation of trees and shrubs. Utah State University Cooperative Extension, 1-5.

3. Danielewicz W. and Wiatrowska B. 2014. The most invasive tree and shrub species in Polish forests. Peckiana, 9, 59-67. (in Polish)

4. Frączek J., Mudryk K. and Wróbel M. 2009. Ashleaved maple Acer negundo L. - the new potential energy species. Acta Agrophysica, 14(2), 313-322. (in Polish)

5. KlimekA., Rolbiecki S., Rolbiecki R., Hilszczańska D. and Malczyk P. 2011. Effects of organic fertilization and mulching under micro-sprinkler irrigation on growth and mycorrhizal colonization of European larch seedlings, and occurrence of soil mites. Polish Journal of Environmental Studies, 5(20), 1211-1219.

6. Klimek A., Rolbiecki S., Rolbiecki R., Długosz J. and Musiał M. 2013. The use of compost from sewage sludge and forest ectohumus for enrichment of soils in the nursery cultivation of littleleaf linden (Tilia cordata Mill.). Annual Set The Environment Protection, 15, 2811-2828.

7. Kuchar L., Iwański S., Diakowska E. and Gąsiorek E. 2015. Simulation of hydrothermal conditions for crop production purpose until 2050-2060 and selected climate change scenarios for North Central Poland. Infrastructure and Ecology of Rural Areas II(1), 319-334.

8. Kuchar L., Iwański S., Diakowska E. and Gąsiorek E. 2017. Assessment of meteorological drought in 2015 for North Central part of Poland using hydrothermal coefficient (HTC) in the context of climate change. Infrastructure and Ecology of Rural Areas, I(2), 257-273.

9. Łabędzki L. 2009. Foreseen climate changes and irrigation development in Poland. Infrastructure and Ecology of Rural Areas, 3, 7-18.

10. Łabędzki L., Bąk B. and Liszewska M. 2013. Impact of climate change on water demand of late potato. Infrastructure and Ecology of Rural Areas, 2(I), 155-165. (in Polish)

11. Pacewicz K., Wróbel M., Wieczorek T., Gilewska M. and Otremba K. 2006. Growth characteristics of Acer negundo, Eleagnus angustifolius and Robinia pseudoacacia trees on wet ash disposal site. Acta Scientarium Polonarum, Formatio Circumiectus 5(1), 87-98. (in Polish)

12. Ptach W., Łangowski A., Rolbiecki R., Rolbiecki S., Jagosz B., Grybauskiene V. and Kokoszewski M. 2017. The influence of irrigation on the growth of paulownia trees at the first year of cultivation in a light soil. Proc. 8th International Scientific
Conference Rural Development 2017, 764-768.

13. Ranney T.G., Whitlow T.H. and Bassuk N.L. 1990. Response of five temperate deciduous tree species to water stress. Tree Physiology, 6, 439-448.

14. Roberts B.R. and Schnipke V.M. 1987. Water requirements of five container-grown Acer species. Journal of Environmental Horticulture, 5(4), 173175.

15. Rolbiecki S., Rolbiecki R., Rzekanowski Cz., Żarski J. 2000. The influence of sprinkler irrigation on yields of some vegetable crops in the region of Bydgoszcz, Poland. Acta Horticulturae, 537, 871877.

16. Rolbiecki S., Kokoszewski M., Grybauskiene V., Rolbiecki R., Jagosz B., Ptach W. and Langowski A. 2017. Effect of expected climate changes on the water needs of forest nursery in the region of central Poland. Proc. 8th International Scientific Conference Rural Development 2017, 786-792.

17. Rzekanowski C., Pierzgalski E. 2006. Irrigation of forest nurseries. In: S. Karczmarczyk and L. Nowak (Eds). Plant irrigation. PWRiL, Poznań, 194-197.

18. Sjöman H., Hirons A.D. and Bassuk N.L. 2015. Urban forest resilience through tree selection - Variation in drought tolerance in Acer. Urban Forestry \& Urban Greening, 14, 858-865.

19. Stachowski P. 2009. Purposefulness of spray irrigation during agricultural cultivation of postmining grounds. Annual Set of Environment Protection, 11, 1131-1142.

20. Stachowski P. and Markiewicz J. 2011. The need of irrigation in central Poland on the example of Kutno county. Annual Set of Environment Protection, 13, 1453-1472.

21. White J.C. and Smith W.K. 2013. Water sources in riparian trees of the southern Appalachian foothills, U.S.A.: A preliminary study with stable isotope analysis. Riparian Ecology and Conservation, $1,46-52$.

22. White J.C. and Smith W.K. 2015. Seasonal variation in water sources of the riparian tree species Acer negundo and Betula nigra, southern Appalachian foothills, USA. Botany, 93, 519-528.

23. Żakowicz S. 2010. Principles of irrigation technology of restoration municipal wastes landfills. Ed. SGGW, Treatises and Monographs, 1-95. (in Polish)

24. Żakowicz S., Hewelke P., Gnatowski T. 2009. Basics of technical infrastructure in the agricultural space. Ed. SGGW. Warszawa, 1-192. (in Polish)

25. Żakowicz S., Hewelke P. 2012. Plant irrigation technology on restoration municipal wastes landfills. Ed. SGGW, Warszawa, 1-155. (in Polish)

26. Żarski J., Dudek S., Kuśmierek-Tomaszewska R., Rolbiecki R. and Rolbiecki S. 2013. Forecasting effects of plants irrigation based on selected meteorological and agricultural drought indices. Annual Set The Environment Protection, 15, 2185-2203. 